\title{
Does postural sway change in association with manual therapeutic interventions? A review of the literature
}

\author{
Alexander Ruhe ${ }^{1,2^{*}}$, René Fejer ${ }^{3}$ and Bruce Walker ${ }^{1}$
}

\begin{abstract}
Study design: Literature Review

Objectives: The objective of this literature review was to determine if postural sway changes in association with manual therapeutic interventions and to investigate whether any changes occur in healthy individuals or in association with pain intensity.

Summary of Background data: Improving postural stability has been proposed as a goal of manual therapeutic interventions. So far, no literature review has addressed whether there is supportive evidence for this and if so, what factors may be associated or causative for observed sway alterations.

Search methods: Seven online databases (PubMed, MEDLINE, EMBASE, CINAHL, Web of Science, ScienceDirect and the Cochrane library) were systematically searched followed by a manual search of the retrieved papers.

Selection criteria: Studies comparing postural sway derived from bipedal force plate measurements in association with a manual therapeutic intervention, ideally compared to a control group.

Data collection and analysis: Two reviewers independently screened titles and abstracts for relevance, conducted the data extraction and the risk of bias assessment which was conducted using the RTI item bank. A descriptive analysis was conducted as the heterogeneous study designs prevented pooling of data.

Results: Nine studies of varying methodological quality met the inclusion criteria. No direct comparison of data across the studies was possible. There was no evidence that manual interventions lead to a change in postural sway in healthy individuals regardless of the body regions addressed by the intervention. There was some indication that postural sway may change at follow-up measurements in pain sufferers; however, this may be due to variations in pain intensity rather than resulting from the intervention itself.
\end{abstract}

Conclusions: There is no conclusive scientific evidence that manual therapeutic interventions may exhibit any immediate or long-term effect on COP excursions. Any changes in sway may be attributable to decreases in pain intensity.

Keywords: Center of pressure, Postural sway, Manual therapy, Intervention

\footnotetext{
* Correspondence: alexander ruhe@hotmail.com

'School of Health Professions, Murdoch University, Murdoch, Western

Australia, Australia

${ }^{2}$ Praxis fuer Chiropraktik Wolfsburg, Wolfsburg, Germany

Full list of author information is available at the end of the article
} 


\section{Background}

Restoring postural stability and balance has been advocated as one goal of therapeutic interventions throughout the physical medicine professions [1] and changes in center of pressure (COP) excursions as a measure of balance performance in association with therapeutic exercise [2-4] or balance training [5-7] are well documented in the literature.

After applying spinal manipulation as an intervention, several studies have reported treatment effects on differences in weight distribution between the lower extremities [8] and balance performance by means of the Berg balance scale (BBS) [9-12].

It appears likely that any change in COP excursions associated with manual interventions is due to a reduction in pain perception $[13,14]$. In addition, it may be speculated that a therapeutic intervention capable of increasing somatosensory function may be beneficial for postural stability. For example, spinal manipulative therapy (SMT) of the cervical spine has been shown to improve proprioception $[15,16]$, although the underlying mechanism(s) remains unclear.

Despite the theoretical neuro-physiological associations between spinal manipulation and postural stability, only a few studies have been published and thus the evidence of the mechanisms of spinal manipulation on COP excursions remains unclear. This literature review will present and critically comment on the current state of knowledge.

The objective of this literature review is to 1) determine if there are significant changes in postural stability associated with manual therapeutic interventions, 2) investigate whether these changes occur in pain sufferers, healthy individuals or both and 3) whether any observed postural sway alterations are related to factors such as pain intensity associated with the underlying condition of the symptomatic individuals.

\section{Methodology}

For the purpose of this review, AR acted as the principal reviewer. A colleague experienced in literature review data extraction was involved independently in the process of identifying relevant studies but did not participate in further analysis of the finally included papers.

\section{Search strategy}

A comprehensive search strategy was developed to identify all potentially relevant studies.

Basic inclusion criteria were those studies investigating postural sway exhibited by symptomatic or asymptomatic individuals on a forceplate following some form of manual therapeutic interventions such as manipulation, mobilization or massage. Studies employing rehabilitative interventions such as proprioceptive training or muscle strengthening exercises only were excluded.

Key indexing terms were categorized into specific search phrases and subsequently combined by using Boolean terms. This search strategy was applied to seven different electronic databases: PubMed, MEDLINE, EMBASE, CINAHL, Web of Science, ScienceDirect and the Cochrane library. The date range of publications searched was from January 1980 to May 2012.

A subsequent hand search was conducted through the reference lists of all the included studies. Citation searches of relevant studies were conducted using the PubMed, MEDLINE and ScienceDirect databases.

This search strategy Initially provided only a limited yield, accordingly the inclusion and exclusion criteria were extended to include any type of publication in order not to miss potentially relevant papers.

\section{Risk of bias assessment}

A risk of bias assessment was conducted independently by two reviewers (AR and RF) in order to determine the quality of the included studies. Recently, Viswanathan et al. have identified 29 practical and validated items that may be used to evaluate the risk of bias and precision of observational studies [17]. This bank of items covers a range of different study designs and the authors have provided instructions as to what items to use depending on the studies under assessment.

Thus, only five items related to our main objectives were included and criteria for each item were defined to fit our main objective (Table 1). The layout of the questionnaire was slightly modified for practical reasons, but no other changes were made. The chosen items focused on selection bias, precision, performance and information bias, and the overall interpretation of each study. Relevant criteria to assist in determining the risk of bias in a study were specified to each item. No validation of the included items was performed.

Comparing post-intervention results with baseline values may be deemed sufficient to assess for a treatment effect. However, Question 9 was included in the risk of bias assessment as a comparison group is useful to determine whether changes in the outcome measures were due to the intervention or effects of learning or fatigue due to repetitive testing.

Where authors did not provide information on the reliability of postural sway assessment, a judgment of methodology was made based on a previous systematic review of the literature. For example, three repetitions of $90 \mathrm{sec}$ measuring duration in narrow stance (feet together) with eyes closed were deemed appropriate [18].

It was decided that a study with one or more of the key items being rated negative or unclear could not be rated as of low risk of bias. 
Table 1 RTI Items elected to assess risk of bias and precision of the included studies

\begin{tabular}{|c|c|c|c|c|}
\hline $\begin{array}{l}\text { Item number from } \\
\text { original study* }\end{array}$ & $\begin{array}{l}\text { Dimension } \\
\text { of bias }\end{array}$ & $\begin{array}{l}\text { Methods } \\
\text { domain }\end{array}$ & Assessment question & Criteria / definitions / categories \\
\hline \multirow[t]{2}{*}{2} & \multirow{2}{*}{$\begin{array}{l}\text { Selection } \\
\text { bias }\end{array}$} & \multirow{2}{*}{$\begin{array}{l}\text { Sample definition } \\
\text { and selection }\end{array}$} & \multirow{2}{*}{$\begin{array}{l}\text { Are critical inclusion/ exclusion } \\
\text { criteria clearly stated? }\end{array}$} & - Age range, gender, etc. described? \\
\hline & & & & - Specific inclusion/exclusion criteria stated? \\
\hline \multirow[t]{2}{*}{6} & \multirow[t]{2}{*}{ Precision } & \multirow{2}{*}{$\begin{array}{l}\text { Sample definition } \\
\text { and selection }\end{array}$} & \multirow{2}{*}{$\begin{array}{l}\text { Was the sample size sufficiently large } \\
\text { to detect a significant difference } \\
\text { between groups? }\end{array}$} & • Justification for selected sample size given? \\
\hline & & & & -Were sample size calculations performed? \\
\hline \multirow[t]{2}{*}{7} & \multirow[t]{2}{*}{$\begin{array}{l}\text { Performance } \\
\text { bias }\end{array}$} & \multirow{2}{*}{$\begin{array}{l}\text { Interventions/ } \\
\text { exposure } \\
\text { outcomes }\end{array}$} & \multirow[t]{2}{*}{$\begin{array}{l}\text { What is the level of detail in } \\
\text { describing the intervention? }\end{array}$} & $\begin{array}{l}\text { - Type of intervention, timing and } \\
\text { frequency described? }\end{array}$ \\
\hline & & & & -Was the intervention identical for all participants? \\
\hline \multirow[t]{3}{*}{9} & \multirow{3}{*}{$\begin{array}{l}\text { Selection } \\
\text { bias }\end{array}$} & \multirow{3}{*}{$\begin{array}{l}\text { Creation of } \\
\text { treatment groups }\end{array}$} & \multirow{3}{*}{$\begin{array}{l}\text { Is the selection of the comparison } \\
\text { group appropriate }\end{array}$} & •Is there a comparison/ control group? \\
\hline & & & & $\begin{array}{l}\text { - If so, are there fundamental differences between the } \\
\text { groups on the basis of socio-demographic variables } \\
\text { and the outcome variables at baseline? }\end{array}$ \\
\hline & & & & $\begin{array}{l}\text { - Do the controls represent the population from } \\
\text { which the intervention group arose? }\end{array}$ \\
\hline \multirow[t]{10}{*}{15} & \multirow[t]{10}{*}{$\begin{array}{l}\text { Information } \\
\text { bias }\end{array}$} & \multirow[t]{10}{*}{$\begin{array}{l}\text { Soundness of } \\
\text { information }\end{array}$} & \multirow[t]{7}{*}{$\begin{array}{l}\text { Are the outcomes assessed using } \\
\text { reliable measures? }\end{array}$} & $\begin{array}{l}\text { - Was the reliability of the outcome assessment } \\
\text { tested? }\end{array}$ \\
\hline & & & & $\begin{array}{l}\text { - If not, is the measurement protocol likely to yield } \\
\text { reliable/valid results with regards to }\end{array}$ \\
\hline & & & & - sampling duration \\
\hline & & & & - number of repetitions \\
\hline & & & & - visual condition \\
\hline & & & & - foot position \\
\hline & & & & based on a systematic review of the literature [18] \\
\hline & & & \multirow[t]{3}{*}{ Overall judgment } & $\begin{array}{l}\text { - Low risk of bias: Bias, if present, is unlikely to alter } \\
\text { the results seriously }\end{array}$ \\
\hline & & & & $\begin{array}{l}\text { - Unclear risk of bias: Impossible to determine risk of } \\
\text { bias (either missing or not described well enough) }\end{array}$ \\
\hline & & & & - High risk of bias: Bias may alter the results seriously \\
\hline
\end{tabular}

* [17].

\section{Data analysis}

A descriptive analysis was conducted as the included studies were significantly heterogeneous with regards to study design, intervention, characteristics of participants and outcome measures (e.g. postural sway parameters and experimental procedures), which prevented any pooling of data.

\section{Results}

\section{Study selection}

The second and final database search strategy identified 356 studies of which all abstracts were screened. The application of inclusion and exclusion criteria eliminated 339 papers. From the 17 remaining articles, the full text of the papers was reviewed and 8 more were eliminated leaving 9 studies finally included in this review. Of these, six were published in peerreviewed journals [19-24], one of them as a single case study [20]. The remaining studies were undergraduate student projects (Figure 1).

\section{Risk of bias assessment}

The risk of bias assessment showed that all studies were of high or unclear risk. None of the included studies provided sample size calculations to investigate when statistically significant differences pre- and post-intervention or between intervention and control groups could be reached.

Only two of the included studies tested the reliability of the experimental setup used and found satisfactory results (ICC $\geq 0.75$ ) [22,23]. For the remaining studies, the expected reliability of the postural sway measures based on methodological recommendations in a previous literature review [18] was low or unclear (Table 2).

\section{Characteristics of participants}

While the participant's demographics have been shown to affect postural sway measures $[25,26]$, only half of the studies provided sufficient details on socio-demographic information.

Apart from the case study [20], all other studies used small mixed gender groups of 17 [19] to 42 [27] participants. 


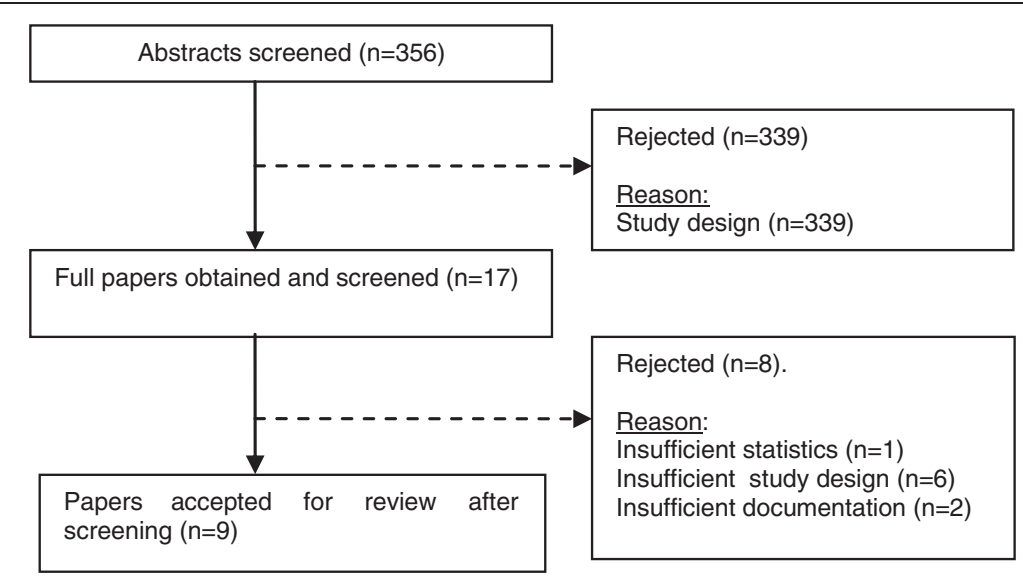

Figure 1 Flowchart of papers.

The mean age ranged from 22.5 (SD 5.7) [27] to 74.5 (SD 9.6) [19] years. With regards to symptomatic participants, two studies enrolled individuals with neck pain $[20,21]$ and one enrolled patients with non-specific low back pain (NSLBP) [22]. Otherwise, healthy individuals were used (Table 3).

\section{Characteristics of the interventions}

With three exceptions $[23,28,29]$, the studies used combinations of different forms of manual therapeutic and/ or exercise interventions.

The majority of studies based their conclusions on a single session with follow-up COP measurements immediately following baseline measurement and intervention [19,23,28-30]. The others used about one week [31] to 3 month follow-up [21]. A comprehensive overview about procedures and results is presented in Table 4.

\section{Changes in COP associated with manual therapeutic interventions}

In the study by Jones [27], a single osteopathic high velocity, low amplitude (HVLA) manipulation was targeted to the lumbar region between L1 and L5, depending on the physical examination findings. Furthermore, "muscle energy technique" was included and involved three repetitions of seven isometric contractions and soft tissue techniques were applied bilaterally to the lumbar paraspinal musculature for $45 \mathrm{sec}$. While a significant, immediate reduction in post-intervention mean sway velocity $(\mathrm{mVel})$ was noted in tandem stance with both eyes open $(p=.003)$ and eyes closed $(p=.001)$, no differences were observed in normal or unipedal stance under either visual condition.

Persson et al. [21] applied manual therapies such as massage while excluding SMT for their group of neck pain sufferers. After 15 applications of therapeutic massage to the neck area and exercise sessions over a 3 month period, no significant post-treatment changes in COP sway were identified and no significant reduction in the perceived pain intensity as assessed by VAS occurred.

The intervention program set up by Lafond et al. [20] for their single case study was diverse and involved HVLA manipulation to the cervical spine in combination with different forms of physical rehabilitation and exercise. A

Table 2 Assessment of risk of bias and precision

\begin{tabular}{|c|c|c|c|c|c|c|}
\hline Study & Q2 & Q6 & Q7 & Q9 & Q15 & Overall judgment on risk of bias \\
\hline Persson et al. [21] & + & - & + & - & - & unclear \\
\hline Lafond et al. [20] & unclear & - & + & - & unclear & high \\
\hline Jones [27] & - & - & + & - & unclear & unclear \\
\hline Vaillant et al. [19] & unclear & - & unclear & - & - & high \\
\hline Nolan [28] & + & - & + & - & unclear & unclear \\
\hline Ruhe et al. [22] & + & - & + & - & + & unclear \\
\hline Levy et al. [29] & unclear & - & - & + & + & unclear \\
\hline Alburguerque-Sendin et al. [23] & unclear & - & + & unclear & unclear & unclear \\
\hline Giemza et al. [24] & + & - & + & + & - & unclear \\
\hline
\end{tabular}

+ : yes, - : no. 
Table 3 Participant demographics and health status

\begin{tabular}{|c|c|c|c|c|c|c|}
\hline \multirow[t]{3}{*}{ Study } & \multirow{3}{*}{$\begin{array}{l}\text { Participant health } \\
\text { status }\end{array}$} & \multicolumn{2}{|c|}{ Gender (n) } & \multirow{3}{*}{$\begin{array}{c}\text { Age } \\
\text { in years } \\
\text { Mean }(\mathrm{SD})\end{array}$} & \multirow{3}{*}{$\begin{array}{c}\text { Weight } \\
\text { in kg } \\
\text { Mean (SD) }\end{array}$} & \multirow{3}{*}{$\begin{array}{l}\text { Height } \\
\text { in cm } \\
\text { Mean (SD) }\end{array}$} \\
\hline & & Female & Male & & & \\
\hline & & & & & & \\
\hline \multirow[t]{3}{*}{ Persson et al. [21] } & Cx root compression & & & & & \\
\hline & physiotherapy & 14 & 10 & $47(8)$ & $75(16)$ & $171(2)$ \\
\hline & healthy & 8 & 12 & $45(9)$ & $75(12)$ & $177(11)$ \\
\hline Lafond et al. [20] & chronic neck pain & 1 & 0 & 45 & - & - \\
\hline Jones [27] & healthy & 23 & 19 & $22.5(5.7)$ & - & - \\
\hline Vaillant et al. [19] & healthy & 0 & 17 & $74.5(9.6)$ & $73.2(12.3)$ & $165.6(9.3)$ \\
\hline Nolan [28] & unclear & 12 & 10 & $18-45$ & - & - \\
\hline Ruhe et al. [22] & NSLBP & 21 & 17 & $39.8(10.5)$ & $79.3(12.4)$ & $178.1(8.4)$ \\
\hline Levy et al. [29] & healthy & \multicolumn{2}{|c|}{ unclear(12 total) } & $20-50$ & - & - \\
\hline Alburguerque-Sendin et al. [23] & healthy & 23 & 9 & $21.9(3.4)$ & - & - \\
\hline \multirow[t]{2}{*}{ Giemza et al. [24] } & hip osteoarthritis & 0 & 80 & $68.5(3.7)$ & $75.7(9.4)$ & $169.6(6.8)$ \\
\hline & healthy & 0 & 30 & $69.3(3.2)$ & $74.0(7.5)$ & $172.3(5.1)$ \\
\hline
\end{tabular}

Cx: cervical, NSLBP: non-specific low back pain.

- : not described.

significant reduction in postural sway post-intervention was noted for all included parameters. Mean sway velocity, for example, decreased by $44.1 \%$ (AP, eyes open) and to $50.5 \%$ (ML, eyes open) after 16 interventions over 8 weeks. The reduction in COP excursions was accompanied by a clinically significant decrease in pain perception from VAS 60 to 20.

Vaillant et al. [19] conducted manual mobilizations of the feet in all planes. Before and after the therapeutic manipulation, the healthy participants exhibited very similar COP displacements with eyes open. With eyes closed, a decrease in postural sway was observed particularly in ML direction. However, this difference was non-significant.

Nolan [28] used the Stability Index (SI) to investigate the immediate effect of cervical HVLA manipulation on postural stability in asymptomatic individuals. The SI represents the variance of the force platform displacement in degrees from a level position in all positions. Greater amounts of body movements are associated with increasing SI values [32]. A statistically significant reduction in post-intervention SI magnitude was noted in the intervention group in both AP and ML direction while the results of the placebo group remained fairly constant.

Alburguerque-Sendin et al. [23] did not find that bilateral talocrural joint manipulation changed COP excursions in healthy subjects. They noted a non-significant trend towards small differences between intervention group and controls not receiving an intervention.

When Giemza et al. [24] assessed postural sway in a group of patients with hip osteoarthritis before and after kinesiotherapy (e.g. massage, exercise), they noted a statistically significant sway decrease post-intervention $(\mathrm{p}<0.01)$.

A recent study investigated whether changes in pain intensity would result in changes in the magnitude COP excursions [22]. For this purpose, postural sway was measured according to a best practice experimental setup [18] following non-specific chiropractic "usual care" manual therapeutic interventions. The authors did not include a placebo group as no conclusions regarding causality were intended with regards to changes in COP excursions. However, in this study, a statistically significant overall decrease in both sway velocity and area was observed at the third session following the interventions compared to baseline. Where no pain reduction was achieved there was no corresponding change in COP excursions.

Levy et al. [29] enrolled two groups of chiropractic students. The intervention group $(n=12)$ received "instrument-applied manipulation(s)" according to "previous scan findings", while for the controls $(n=11)$ an unspecified sham treatment was applied. Postural sway measures of both groups were obtained before and after. Only during one of the four postural tasks, where COP was measured post-intervention with eyes closed on a foam surface, a significant decrease in postural sway was noted compared to baseline $(\mathrm{p}<0.05)$.

\section{Discussion}

Large scale studies investigating changes in COP excursions associated with manual therapy have been announced at scientific conferences but are yet to be published [33]. COP measures have also been specifically suggested as a monitoring tool for chiropractic practice 
Table 4 COP excursions associated with therapeutic interventions

\begin{tabular}{|c|c|c|c|c|c|c|c|c|c|c|}
\hline \multirow[t]{3}{*}{ Study } & \multirow[t]{3}{*}{ Intervention } & \multirow{3}{*}{$\begin{array}{c}\text { Sampling duration } \\
\text { (sec) }\end{array}$} & \multirow{3}{*}{$\begin{array}{l}\text { Follow-up } \\
\text { period }\end{array}$} & \multicolumn{3}{|c|}{ Experimental setup } & \multicolumn{4}{|c|}{ Results } \\
\hline & & & & \multirow{2}{*}{$\begin{array}{l}\text { Number of } \\
\text { repetitions }\end{array}$} & \multirow{2}{*}{$\begin{array}{c}\text { COP } \\
\text { parameter }\end{array}$} & \multirow{2}{*}{$\begin{array}{l}\text { Postural } \\
\text { task }\end{array}$} & \multicolumn{2}{|c|}{ Postural sway } & \multicolumn{2}{|c|}{ Pain intensity } \\
\hline & & & & & & & $\begin{array}{c}\text { Pre- } \\
\text { intervention }\end{array}$ & $\begin{array}{c}\text { Post- } \\
\text { intervention }\end{array}$ & $\begin{array}{c}\text { Pre- } \\
\text { intervention }\end{array}$ & $\begin{array}{c}\text { Post- } \\
\text { intervention }\end{array}$ \\
\hline \multirow[t]{3}{*}{ Persson et al. [21] } & Physiotherapy & 10 & 12 weeks & 1 & mVel (mm/s) & $\begin{array}{l}\text { narrow } \\
\text { stance }\end{array}$ & & & & \\
\hline & Total: $15 x$ e.g. exercise, massage & & & & & $\mathrm{EO} / \mathrm{F}$ & 11.4 & 12.9 & 47 (8) VAS & 39 (29) VAS \\
\hline & & & & & & $\mathrm{EC} / \mathrm{F}$ & 15.8 & 15.6 & & \\
\hline \multirow[t]{11}{*}{ Lafond et al. [20] † } & Total: & 30 & 8 weeks & 1 & mVel AP & $\begin{array}{l}\text { narrow } \\
\text { stance }\end{array}$ & & & 60 (VAS) & 20 (VAS) \\
\hline & Spinal manipulation & & & & $(\mathrm{mm} / \mathrm{s})$ & $\mathrm{EO} / \mathrm{F}$ & $\sim 10.0$ & $\sim 5.5$ & & \\
\hline & 16x cervical (HVLA) & & & & & $\mathrm{EC} / \mathrm{F}$ & $\sim 13.0$ & $\sim 7.5$ & & \\
\hline & C2/3 level & & & & mVel ML & $\begin{array}{l}\text { narrow } \\
\text { stance }\end{array}$ & & & & \\
\hline & Rehabilitation & & & & $(\mathrm{mm} / \mathrm{s})$ & $\mathrm{EO} / \mathrm{F}$ & $\sim 6.0$ & $\sim 2.0$ & & \\
\hline & 16x strengthening & & & & & $\mathrm{EC} / \mathrm{F}$ & $\sim 7.5$ & $\sim 2.0$ & & \\
\hline & 16x oculomotor & & & & area $\left(\mathrm{mm}^{2}\right)$ & $\begin{array}{l}\text { narrow } \\
\text { stance }\end{array}$ & & & & \\
\hline & exercise & & & & & $\mathrm{EO} / \mathrm{F}$ & 86.0 & 100.3 & & \\
\hline & 16x balance & & & & & $\mathrm{EC} / \mathrm{F}$ & - & - & & \\
\hline & exercise & & & & & & & & & \\
\hline & 16x stretching & & & & & & & & & \\
\hline \multirow[t]{9}{*}{ Jones [27] } & 1x Spinal manipulation & unclear & $\begin{array}{l}\text { same } \\
\text { dayo }\end{array}$ & unclear & mVel (mm/s) & $\begin{array}{l}\text { normal } \\
\text { stance }\end{array}$ & & & N/A & N/A \\
\hline & lumbar (HVLA) & & & & & $\mathrm{EO} / \mathrm{F}$ & $4.5(1.7)$ & $4.3(1.8)$ & & \\
\hline & 1x Muscle energy & & & & & $\mathrm{EC} / \mathrm{F}$ & $6.0(2.2)$ & $5.4(3.0)$ & & \\
\hline & technique & & & & & $\begin{array}{l}\text { unipedal } \\
\text { stance }\end{array}$ & & & & \\
\hline & 1x Myofascial & & & & & $\mathrm{EO} / \mathrm{F}$ & $17.3(6.1)$ & $17.0(3.6)$ & & \\
\hline & technique & & & & & $\mathrm{EC} / \mathrm{F}$ & $38.6(11.5)$ & 35.4 (11.9) & & \\
\hline & & & & & & $\begin{array}{l}\text { tandem } \\
\text { stance }\end{array}$ & & & & \\
\hline & & & & & & $\mathrm{EO} / \mathrm{F}$ & $14.7(5.5)$ & $12.0(4.4)^{* *}$ & & \\
\hline & & & & & & $\mathrm{EC} / \mathrm{F}$ & $25.8(9.6)$ & $21.4(8.1) * * *$ & & \\
\hline Vaillant et al. [19] † & Mobilization & EO: 4 & $\begin{array}{l}\text { same } \\
\text { dayo }\end{array}$ & 6 & $\begin{array}{l}\text { displacement } \\
\text { AP }(\mathrm{mm})\end{array}$ & $\begin{array}{l}\text { narrow } \\
\text { stance }\end{array}$ & & & $\mathrm{N} / \mathrm{A}$ & $\mathrm{N} / \mathrm{A}$ \\
\hline
\end{tabular}


Table 4 COP excursions associated with therapeutic interventions (Continued)

\begin{tabular}{|c|c|c|c|c|c|c|c|c|c|c|}
\hline & $1 \mathrm{x}$ ankle/feet & EC: 8 & & 6 & & $\mathrm{EO} / \mathrm{F}$ & 36 & 34 & & \\
\hline & Massage & & & & $\begin{array}{l}\text { displacement } \\
\mathrm{ML}(\mathrm{mm})\end{array}$ & $\mathrm{EC} / \mathrm{F}$ & $62-68$ & $58-62$ & & \\
\hline & $1 \mathrm{x}$ ankle/feet & & & & & $\begin{array}{l}\text { narrow } \\
\text { stance }\end{array}$ & & & & \\
\hline & & & & & & $\mathrm{EO} / \mathrm{F}$ & 47 & 42 & & \\
\hline & & & & & & $\mathrm{EC} / \mathrm{F}$ & $74-88$ & $67-70$ & & \\
\hline \multirow[t]{3}{*}{ Nolan $[28] \dagger$} & Manipulation & 60 & $\begin{array}{l}\text { same } \\
\text { day } \infty\end{array}$ & 2 & stability index & $\begin{array}{l}\text { normal } \\
\text { stance }\end{array}$ & & & N/A & N/A \\
\hline & 1x cervical (HVLA) & & & & & EO/F AP & 2.90 & 2.10 & & \\
\hline & C0/1, C1/2 level & & & & & EO/F ML & 2.55 & 1.65 & & \\
\hline \multirow[t]{5}{*}{ Levy et al. [29] } & Instrument-applied manipulation & 10 & same & 1 & sway velocity & $\begin{array}{l}\text { unclear } \\
\text { stance }\end{array}$ & & & N/A & N/A \\
\hline & (Pro-Adjuster System) & & day $\infty$ & & $(\mathrm{deg} / \mathrm{sec}) ?$ & $\mathrm{EO} / \mathrm{F}$ & $0.24(0.11)$ & $0.22(0.16)$ & & \\
\hline & & & & & & $\mathrm{EC} / \mathrm{F}$ & $0.23(0.14)$ & $0.19(0.11)$ & & \\
\hline & & & & & & $\mathrm{EO} / \mathrm{C}$ & $0.61(0.19)$ & $0.53(0.15)$ & & \\
\hline & & & & & & $\mathrm{EC} / \mathrm{C}$ & $1.73(0.49)$ & $1.33(0.41)^{*}$ & & \\
\hline \multirow[t]{4}{*}{$\begin{array}{l}\text { Alburguerque-Sendin } \\
\text { et al. [23] }\end{array}$} & Manipulation & 60 & same & 1 & area $\left(\mathrm{mm}^{2}\right)$ & $\begin{array}{l}\text { unclear } \\
\text { stance }\end{array}$ & & & N/A & N/A \\
\hline & $1 \times$ talocrural joint & & day $\infty$ & & mVel AP/ML & EO/F area & $85.5(122.3)$ & $52.8(48.1)$ & & \\
\hline & & & & & $(\mathrm{mm} / \mathrm{s})$ & $\begin{array}{l}\mathrm{EO} / \mathrm{F} \mathrm{mVel} \\
\mathrm{AP}\end{array}$ & $2.5(0.6)$ & $2.4(0.5)$ & & \\
\hline & & & & & & $\begin{array}{l}\mathrm{EO} / \mathrm{F} \mathrm{mVel} \\
\mathrm{ML}\end{array}$ & $3.0(0.7)$ & $2.9(0.6)$ & & \\
\hline \multirow[t]{7}{*}{ Ruhe et al. [22] } & Spinal and extremity & 90 & $\sim 1$ week & 3 & $\begin{array}{l}\mathrm{mVel} A P / M L \\
(\mathrm{~mm} / \mathrm{s})\end{array}$ & $\begin{array}{l}\text { narrow } \\
\text { stance }\end{array}$ & & & & \\
\hline & $3 x$ manipulation & & & & & $\mathrm{EC} / \mathrm{F} \mathrm{AP}$ & $13.2(2.9)$ & $11.1(2.3) * * *$ & $5.6(2.0)$ & $2.9(1.6)$ \\
\hline & (HVLA) & & & & & EC/F ML & $16.0(2.7)$ & $13.1(3.0) * * *$ & (NRS-11) & (NRS-11) \\
\hline & and mobilization & & & & & & & & & \\
\hline & $3 \times$ Soft tissue & & & & & & & & & \\
\hline & techniques & & & & & & & & & \\
\hline & (e.g. PIR, ART) & & & & & & & & & \\
\hline \multirow[t]{2}{*}{ Giemza et al. [24] } & $\begin{array}{l}\text { Exercise, massage, PIR, cryotherapy, } \\
\text { diathermy, laser }\end{array}$ & 20 & 6 weeks & 1 & & $\begin{array}{l}\text { normal } \\
\text { stance }\end{array}$ & & & "great pain" & unclear \\
\hline & & & & & $\begin{array}{l}\text { area }\left(\mathrm{mm}^{2}\right) \\
\text { AP/ML }\end{array}$ & $E O / F A P$ & $65.8(24.2)$ & $14.8(17.4)^{* *}$ & & \\
\hline
\end{tabular}


Table 4 COP excursions associated with therapeutic interventions (Continued)

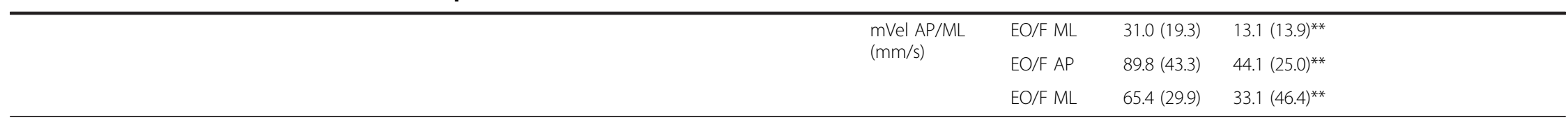

† "Same day" refers to a single session consisting of pre-intervention measurement, intervention and post-intervention measurement.

Results are presented as Mean (SD).
Levels of significance compared to baseline: ${ }^{*} p \leq 0.05,{ }^{* *} p \leq 0.01,{ }^{* * *} p \leq 0.001$.

Levels of significance
$-:$ not described.

- : not described.

mVel: mean velocity, N/A: not applicable, PIR: Post-Isometric Relaxation. 
[1]. This, however, is premature. So far only a few studies have been reported and three of these were undergraduate theses [28-30] that have not been additionally published in a peer reviewed journal to this point.

COP measures are used by some practitioners applying manual therapies, so the lack of good quality studies may suggest that publication bias may play a role. This refers to the tendency on the part of authors to submit, as well as the reviewers and editors to accept, manuscripts based on the study findings [34] as the strongest and most positive studies are most likely to be published [35].

Overall, any interpretation of the reported results is severely limited by a lack of detail in the employed study designs that were often not suited to answer the selfdefined research question $[19,21,24,28,30]$. In addition, the included studies were all found to be either at high or unclear risk of bias.

Important limitations were the absence of a comparison or control/placebo group in all but two studies $[23,29]$, the generally small samples sizes and the often low or unclear reliability of the obtained sway data. For example, the majority of studies generally employed rather short sampling durations. The test-retest variability in postural sway that may occur as a result can lead to the false impression of changes in the outcome measure post-intervention. Although Vaillant et al. [19] used six repetitions, the combined sampling duration of $50 \mathrm{sec}$ was still fairly short which may have adversely affected the results.

In addition, no sample size calculations were reported to assess when statistical significance may be reached between intervention and control/placebo groups. Where multimodal interventions were used [19-22,24,27], the effectiveness of particular treatments remains unclear. In those instances where changes in postural sway were reported $[19,24,30]$, it was not possible to determine whether the intervention itself or learning effects due to repetitive testing [36] may have been causative.

Furthermore, the fact that most studies performed the follow-up measurements immediately after the intervention [19,23,28-30], no conclusions can be reached whether any observed changes are sustained. None of the studies using follow-ups of several weeks $[20,21,24]$ employed multiple measurements at regular intervals that may have allowed an appreciation of associations between pain and postural sway or learning effects due to repetitive testing.

However, it appears that when healthy participants were tested, generally no significant change in postural sway between COP excursions pre- and postintervention was noted $[19,23,30]$. When Nolan reported a significant decrease in postural sway associated with cervical SMT [28] this may be explained by the fact that the Biodex Balance System was the only forceplate used that allowed surface perturbation and a sway degree based COP parameter to be employed.

With regards to the study by Persson et al., there is no conclusive evidence that massage is an effective treatment for cervical nerve root compression [37]. This may at least partly explain why the perceived pain levels did not decrease significantly and, as a correlation between these two factors exists [38], the COP excursions remained similar to pre-intervention stage.

The results reported by Vaillant et al. [19] further indicate that the mobilization intervention either had no immediate effect on postural sway with eyes open, or that any such effect remained undetectable when allowing visual fixation. This is supported by the decrease in COP displacement under visual obstruction.

Finally, the results reported by Giemza et al. [24] warrant some caution. Firstly, the data collected from the thirty healthy controls to be compared to that of the symptomatic patients was not actually reported in the study. Secondly, no symptomatic controls were selected. The 6 weeks interval between the two measurements of questionable reliability does also allow for many factors to influence postural sway, including learning effects. In addition, it was mentioned that the in addition to increasing range of motion, the kinesitherapy also aimed at reducing the "great pain" of the patients. However, no pain levels were recorded pre- and post-intervention that may offer an explanation for changes in postural sway.

Based on the literature available, there is no conclusive evidence that manual therapeutic interventions exhibit any short term effect on body sway, at least in asymptomatic participants, for the COP parameters employed. Other parameters, such as those based on frequency or amplitude, may provide additional insights.

There is weak evidence that a significant decrease in pain perception in symptomatic individuals was associated with decreasing COP excursions [20,22], while at similar pain perception, postural sway remained unchanged [21,22]. Accordingly, it appears likely that the pain reduction itself is responsible for the observed lower postural sway in those experiencing pain relief.

The manual intervention itself on the other hand does not appear to offer any additional biomechanical or neuro-physiological benefit (e.g. by stimulation of joint mechanoreceptors) compared to natural history or the changes in sway observed under analgesic treatment [39]. However, the limitations of the respective included studies do not encourage further hypothesizing about potential underlying mechanisms at this point. At this point, practitioners are discouraged from advertising any effect of manual therapeutic interventions on balance e.g. in fall or injury prevention. 


\section{Conclusion}

Due to the heterogeneous study designs there is no conclusive evidence that manual therapeutic interventions exhibits any immediate or long-term effect on COP excursions in healthy individuals. In pain sufferers, any changes in sway may be attributable to a decrease in pain intensity rather than the intervention itself. Given this heterogeneous reporting, further research needs to implement standardized testing protocols, include control groups, obtain larger sample sizes in order to allow for comprehensive inter-study comparisons and involve follow-up testing.

\section{Competing interests}

The authors declare that they have no competing interests.

\section{Authors' contributions}

$A R$ and RF conducted the literature search and the risk of bias assessment. AR drafted the manuscript and performed the statistical analysis. RF and BW helped with the design of the study and drafting the manuscript. All authors read and approved the final manuscript.

\section{Author details}

${ }^{1}$ School of Health Professions, Murdoch University, Murdoch, Western Australia, Australia. ${ }^{2}$ Praxis fuer Chiropraktik Wolfsburg, Wolfsburg, Germany. ${ }^{3}$ Research Department, Spine Centre of Southern Denmark, Hospital Lillebaelt and University of Southern Denmark, Middelfart, Denmark.

Received: 21 July 2012 Accepted: 31 January 2013

Published: 4 February 2013

\section{References}

1. De Camillis D, Carr R: The reliability and potential value of a specific 'center of pressure locator' in chiropractic practice. J Can Chiro Ass 2000, 44:209-222.

2. Kollmitzer J, Ebenbichler GR, Sabo A, Kerschan K, Bochdansky K: Effects of back extensor strength training versus balance training on postural control. Med Sci Sports Exerc 2000, 32:1770-1776.

3. Kuukkanen TM, Malkia EA: An experimental controlled study on postural sway and therapeutic exercise in subjects with low back pain. Clin Rehab 2000, 14:192-202.

4. Alfieri FM, de Jesus Guirro RR, Teodori RM: Postural stability of elderly submitted to multisensorial physical therapy intervention. Electromyogr Clin Neurophysiol 2010, 50:113-119.

5. Bayouk JF, Boucher JP, Leroux A: Balance training following stroke: effects of task-oriented exercises with and without altered sensory input. Int J Rehabil Res 2006, 29:51-59.

6. Verhagen $E$, Bobbert $M$, Inklaar M, van Kalken $M$, van der Beek A, Bouter $L$, van Mechelen $\mathrm{W}$ : The effect of a balance training programme on centre of pressure excursion in one-leg stance. Clin Biomech 2005, 20:1094-1100.

7. Wolf B, Feys H, De W, van der Meer J, Noom M, Aufdemkampe G: Effect of a physical therapeutic intervention for balance problems in the elderly: a single-blind, randomized, controlled multicentre trial. Clin Rehab 2001, 15:624-636.

8. Childs JD, Piva SR, Erhard RE: Immediate improvements in side-to-side weight bearing and iliac crest symmetry after manipulation in patients with low back pain. J Manip Physiol Ther 2004, 27:306-313.

9. Hawk C, Cambron JA, Pfefer MT: Pilot study of the effect of a limited and extended course of chiropractic care on balance, chronic pain, and dizziness in older adults. J Manip Physiol Ther 2009, 32:438-447.

10. Hawk C, Cambron J: Chiropractic care for older adults: effects on balance, dizziness, and chronic pain. J Manip Physiol Ther 2009, 32:431-437.

11. Strunk RG, Hawk C: Effects of chiropractic care on dizziness, neck pain and balance: a single group, preexperimental, feasibility study. J Chiropr Med 2009, 8:156-164.

12. Hawk C, Pfefer MT, Strunk RG, Ramcharan M, Uhl N: Feasibility study of short-term effects of chiropractic manipulation on older adults with impaired balance. J Chiropr Med 2007, 6:121-131.
13. Bronfort G, Haas M, Evans R, Leininger B, Triano J: Effectiveness of manual therapies: the UK evidence report. Chiropr Osteopat 2010, 18:3.

14. Walker BF, French SD, Grant W, Green S: A Cochrane review of combined chiropractic interventions for low-back pain. Spine 2011, 36:230-242.

15. Palmgren PJ, Sandstrom PJ, Lundqvist FJ, Heikkila H: Improvement after chiropractic care in cervicocephalic kinesthetic sensibility and subjective pain intensity in patients with nontraumatic chronic neck pain. J Man Phys Thera 2006, 29:100-106.

16. Rogers RG: The effects of spinal manipulation on cervical kinesthesia in patients with chronic neck pain: a pilot study. J Man Phys Thera 1997, 20:80-85.

17. Viswanathan M, Berkman ND: Development of the RTI item bank on risk of bias and precision of observational studies. J Clin Epidemiol 2011, 65:163-178.

18. Ruhe A, Fejer R, Walker BF: The test-retest reliability of centre of pressure measures in bipedal static task conditions - a systematic review of the literature. Gait Posture 2010, 32:436-445.

19. Vaillant J, Vuillerme $N$, Janvey A, Louis F, Braujou R, Juvin R, Nougier V: Effect of manipulation of the feet and ankles on postural control in elderly adults. Brain Res Bull 2008, 75:18-22.

20. Lafond D, Champagne A, Cadieux R, Descarreaux M: Rehabilitation program for traumatic chronic cervical pain associated with unsteadiness: a single case study. Chiropr Osteopat 2008, 16:15.

21. Persson L, Karlberg M, Magnusson M: Effects of different treatments on postural performance in patients with cervical root compression. A randomized prospective study assessing the importance of the neck in postural control. J Vestib Res 1996, 6:439-453.

22. Ruhe A, Fejer R, Walker B: Is there a relationship between pain and the magnitude of COP excursions following non-specific manual interventions in patients with non-specific low back pain? BMC Musculoskelet Disord 2012, 13.

23. Alburquerque-Sendin F, Fernandez-de-las-Penas C, Santos-del-Rey M, Martin-Vallejo FJ: Immediate effects of bilateral manipulation of talocrural joints on standing stability in healthy subjects. Man Ther 2009, 14:75-80.

24. Giemza C, Ostrowska B, Matczak-Giemza M: The effect of physiotherapy training programme on postural stability in men with hip osteoarthritis. Aging Male 2007, 10:67-70.

25. Hue O, Simoneau M, Marcotte J, Berrigan F, Dore J, Marceau P, Marceau S, Tremblay A, Teasdale N: Body weight is a strong predictor of postural stability. Gait Posture 2007, 26:32-38.

26. Chiari L, Rocchi L, Cappello A: Stabilometric parameters are affected by anthropometry and foot placement. Clin Biomech 2002, 17:666-677.

27. Jones D, Fryer G, Vaughan G, McLaughlin P: The effect of osteopathic manipulative therapy applied to the lumbar spine on postural stability; A pilot study. School of Health Science: Victoria University; 2004.

28. Nolan JH: The effect of cervical spine chiropractic manipulation on balance. Dep Chiropr: University of Johannesburg; 2009.

29. Levy A, Solomon M, Workman L: A randomized controlled trial of the effects of instrument-applied chiropractic manipulative therapy on balance in asymptomatic participants. Chesterfield: Logan College of Chiropractic; 2005.

30. Jones D, Fryer G, Vaughan B, McLaughlin P: The effect of osteopathic manipulative therapy applied to the lumbar spine on postural stability: a pilot study. Melbourne: Victoria University, School of Health Science; 2004.

31. Ruhe A, Fejer R, Walker B: Pain relief is associated with decreasing postural sway in patients with non-specific low back pain. BMC Musculoskelet Disord 2012, 13:39.

32. Hinman MR: Factors affecting reliability of teh biodex balance system: a summary of four studies. J Sport Rehabil 2000, 9:249-252.

33. Owens E, Xia T, Wilder D, Gudavalli MR, Meeke W: Postural Stability in Patients with Subacute and Chronic Low Back Pain: Changes Seen with Repeat Testing and Foam Challenge. In BioMech 2007. USA: Honolulu; 2007.

34. Dickersin K: The existence of publication bias and risk factors for its occurrence. J Am Med Ass 1990, 263:1385-1389.

35. Chalmers TC, Frank CS, Reitman D: Minimizing the three stages of publication bias. J Am Med Ass 1990, 263:1392-1395

36. Nordahl SH, Aasen T, Dyrkorn BM, Eidsvik S, Molvaer Ol: Static stabilometry and repeated testing in a normal population. Aviat Space Environ Med 2000, 71:889-893.

37. Ezzo J, Haraldsson BG, Gross AR, Myers CD, Morien A, Goldsmith $\mathrm{CH}_{\text {, }}$ Bronfort G, Peloso PM: Massage for mechanical neck disorders: a systematic review. Spine 2007, 32:353-362. 
38. Ruhe $A$, Fejer $R$, Walker $B$ : Is there a relationship between pain intensity and postural sway in patients with non-specific low back pain? BMC Musculo Dis 2011, 12.

39. Chang ST, Chen LC, Chang CC, Chu HY, Tsai KC: Effects of piroxicam-betacyclodextrin sachets on abnormal postural sway in patients with chronic low back pain. J Clin Pharm Ther 2008, 33:495-506.

doi:10.1186/2045-709X-21-9

Cite this article as: Ruhe et al:: Does postural sway change in

association with manual therapeutic interventions? A review of the

literature. Chiropractic \& Manual Therapies 2013 21:9.

\section{Submit your next manuscript to BioMed Central} and take full advantage of:

- Convenient online submission

- Thorough peer review

- No space constraints or color figure charges

- Immediate publication on acceptance

- Inclusion in PubMed, CAS, Scopus and Google Scholar

- Research which is freely available for redistribution 